PACS: $52.40 . \mathrm{Hf}$

\title{
PHASE STATES OF MACROPARTICLES IN PLASMA WITH HOT ELECTRONS AT PRESENCE OF ION BEAM
}

\author{
O.A. Bizyukov, O.D. Chibisov, O.I. Kutenko \\ V. N. Karazin Kharkiv National University \\ 4. Svobody Sq., 61022, Kharkiv, Ukraine \\ e-mail: alekx0930741952@gmail.com \\ Received September 1, 2017
}

The evaporation possibility of micro sized metallic particles during them passage through the region of a magnetized plasma with a Maxwellian velocity distribution with the electron temperature in the range $T_{\mathrm{e}}=1 \ldots 100 \mathrm{eV}$ at presence of an ion beam with the energy in the range $\varepsilon_{\mathrm{b}}=1 \ldots 6 \mathrm{keV}$ is studied theoretically. The floating potential of a macroparticle is obtained using the OML theory, the effect of the electron temperature and the energy of the ion beam on its magnitude is studied. The equation of energy balance on the macroparticle surface is obtained, such energy exchange mechanisms as collisions of particles of an ion beam and plasma particles with the macroparticle, thermal radiation of the macroparticle, as well as cooling due to the evaporation of substance from the macroparticle surface are taken into account. The effect of the temperature of plasma electrons and the ion beam energy on the stationary temperature of the macroparticle is studied. It is shown that for the given plasma and ion beam parameters, the temperature of the copper macroparticle is below the boiling point so that the evaporation of the macroparticle occurs at temperatures below the boiling point. The dependences of the macroparticle evaporation time on the electron temperature and the energy of the ion beam have been obtained.

KEYWORDS: macroparticles, dusty plasma, ion beam, evaporation, electric potential

\section{ФАЗОВЫЕ СОСТОЯНИЯ МАКРОЧАСТИЦ В ПЛАЗМЕ С ГОРЯЧИМИ ЭЛЕКТРОНАМИ В ПРИСУТСТВИИ} ИОННОГО ПУЧКА

А.А. Бизюков, А.Д. Чибисов, А.И. Кутенко

Харьковский национальный университет имени В.Н. Каразина 61022, г. Харьков, пл. Свободы, 4

Теоретически изучается возможность испарения металлических макрочастиц микронных размеров при прохождении через область замагниченной плазмы с электронами, имеющими Максвелловское распределение по скоростям с температурой в диапазоне $\mathrm{T}_{\mathrm{e}}=1 \ldots 100$ эВ, и в присутствии ионного пучка с энергией в диапазоне $\varepsilon_{\mathrm{b}}=1 \ldots 6$ кэВ. В приближении OML теории вычисляется плавающий потенциал макрочастицы, изучается влияние температуры электронов а также энергии ионного пучка на его величину. Получено уравнение баланса энергий на поверхности макрочастицы, при этом принимаются во внимание такие механизмы обмена энергией, как столкновение частиц ионного пучка и частиц плазмы с макрочастицей, тепловое излучение макрочастицы, а также охлаждение за счет испарения вещества с поверхности макрочастицы. Изучается влияние температуры плазменных электронов и энергии ионного пучка на стационарную температуру макрочастицы. Показано, что при заданных параметрах плазмы и ионного пучка такая равновесная температура медной макрочастицы находится ниже точки кипения, так что испарение макрочастицы происходит при температурах ниже температуры кипения. Получены зависимости времени испарения медных макрочастиц от температуры электронов и энергии ионного пучка.

КЛЮЧЕВЫЕ СЛОВА: макрочастицы, пылевая плазма, ионный пучок, испарение, электрический потенциал

\section{ФАЗОВІ СТАНИ МАКРОЧАСТОК В ПЛАЗМІ З ГАРЯЧИМ ЕЛЕКТРОНАМИ В ПРИСУТНОСТІ ІОННОГО} ПУЧКА

О.А. Бізюков, О.Д. Чібісов, О.І. Кутенко

Харківський наиіональний університет імені В.Н. Каразіна 61022, Харків, м. Свободи, 4

Теоретично вивчається можливість випаровування металевих макрочасток мікронних розмірів при проходженні через область замагніченої плазми 3 електронами, що мають розподіл максвела за швидкостями 3 температурою в діапазоні $\mathrm{T}_{\mathrm{e}}=$ $1 \ldots 100 \mathrm{eB}$, і в присутності іонного пучка 3 енергією в діапазоні $\varepsilon_{\mathrm{b}}=1 \ldots 6$ кеВ. У наближенні ОМL теорії обчислюється плаваючий потенціал макрочастки, вивчається вплив температури електронів а також енергії іонного пучка на його величину. Отримано рівняння балансу енергій на поверхні макрочастки, при цьому беруться до уваги такі механізми обміну енергією, як зіткнення частинок іонного пучка і частинок плазми з макрочасткою, теплове випромінювання макрочастки, а також охолодження за рахунок випаровування речовини з поверхні макрочастки. Вивчається вплив температури плазмових електронів і енергії іонного пучка на стаціонарну температуру макрочастки. Показано, що при заданих параметрах плазми $\mathrm{i}$ іонного пучка така рівноважна температура мідної макрочастки знаходиться нижче точки кипіння, так що випаровування макрочастки відбувається при температурах нижче температури кипіння. Отримано залежності часу випаровування мідних макрочасток від температури електронів і енергії іонного пучка.

КЛЮЧОВІ СЛОВА: макрочастки, пилова плазма, іонний пучок, випаровування, електричний потенціал

Plasma which contains micron sized particles of a substance (dust plasma) in the laboratory is mainly formed as a result of plasma sources operation, as well as a result of erosion of surfaces of a vacuum chamber. In technological processes, such as deposition of coatings, plasma treatment of surfaces, at creating of microelectronic devices, etc., the 
presence of dust particles (macroparticles or MPs) in plasma is a negative factor, as it leads to deterioration of such properties of the treated surfaces as porosity of coatings, adhesion of coatings and surface roughness [1-3]. In practice, the most of ways of decreasing the droplet flow on the processed surface are based on separation of the ion flow and the droplet flow by the magnetic fields [3-7].

The aim of this paper is the considering of the possibility of decreasing of the droplets flow due to evaporation of the macroparticles by the heating of plasma electrons at presence of the ion beam.

\section{CHARGING OF THE MP}

It is known that the MP immersed in the plasma is charged as a result of absorption of electrons and ions of plasma, as well as various types of electron emission from the MP surface. The magnitude of the charge determines which way MP interacts with the plasma and is one of the key parameters affecting on the energy balance of the MP. Charge of the MP is determined by the condition that the sum of the electrical currents on the surface of the MP is equal to zero. Calculation of the currents from plasma on the MP at presence of the magnetic field is a difficult problem, however in some cases various approximations are used successfully. In particular, if the magnetic field is not strong enough such the condition

$$
r_{g}>>\lambda_{d}>>a
$$

is correct, where $r_{g}$ is the Larmor radius of electron, $\lambda_{d}$ is the Debye length, $a$ is the MP radius, in a collisionless plasma, for describing of the ion and electron currents on the MP Orbital-Motion-Limited (OML) theory is used [8]. In this paper we consider plasma with the magnetized electrons which temperature $T_{e}$ is in the range $10-100 \mathrm{eV}$, ion temperature $T_{i}$ is $1 \mathrm{eV}$, plasma density $\mathrm{n}_{0}$ is $10^{10}-10^{11} \mathrm{~cm}^{-3}$. Ion beam energy varies in the range $1-6000 \mathrm{eV}$. Strength of the magnetic field $B$ is such that the condition (1) is correct and we can use the OML theory.

According to the OML theory, electron and ion currents from the plasma to the MP surface have the form:

$$
I_{i(e)}=<e n_{0} v_{i(e)} \sigma_{i(e)}^{O M L}>=e \cdot \Gamma_{i(e)},
$$

where $\sigma_{i(e)}^{O M L}=\pi a^{2}\left(1 \pm \frac{2 e \varphi_{a}}{m_{i(e)} v_{i(e)}^{2}}\right)$ is the absorption cross section of ions (electrons) in the OML theory,

and

$$
\Gamma_{i}=\sqrt{8 \pi} a^{2} n_{0} v_{T i}\left(1-e \varphi_{a} / T_{i}\right)
$$

$$
\Gamma_{e}=\sqrt{8 \pi} a^{2} n_{0} v_{T e} \exp \left(-e \varphi_{a} / T_{e}\right)
$$

are the flows of the ions and electrons on the MP surface, $\varphi_{a}$ is the potential of the MP surface, $v_{T i(e)}=\sqrt{T_{i(e)} / m_{i(e)}}$ is the ion (electron) thermal velocities. Electric current of a secondary electron from the MP surface can be found by averaging over all energies of the electrons:

where

$$
I_{e}^{e-e}=<n_{0} e v_{e} \sigma_{e}^{O M L} \delta^{e-e}>
$$

$$
\delta^{e-e}=\delta_{\max } \frac{E-e \varphi_{a}}{E_{m}} \exp \left(2\left(1-\sqrt{\frac{E+e \varphi_{a}}{E_{m}}}\right)\right)
$$

is the secondary emission yield, $E$ is the kinetic energy of primary electron, $E_{m}$ is the electron energy which corresponds to the maximum of secondary emission yield $\delta_{\max }$. Ion beam current in terms of OML theory is:

$$
I_{i}^{b}=e n_{0} v_{i} \sigma_{j}^{O M L}=e \Gamma_{b},
$$

where $v_{i}$ is the ion velocity, $\Gamma_{\mathrm{b}}$ is the flow of the ions on the MP surface.

Secondary electron emission produced by the ion impact (for energies about $1 \mathrm{keV}$ ) we can express through the emission yield $\gamma$ as:

$$
I_{e}^{i-e}=e \gamma \Gamma_{b} .
$$

Taking into account the charging processes described above (2) - (5), the MP potential can be found by solving the equation of electric currents balance:

$$
I_{e}^{e-e}\left(\varphi_{a}\right)+I_{e}^{i-e}\left(\varphi_{a}\right)+I_{i}^{p l}\left(\varphi_{a}\right)+I_{i}^{b}\left(\varphi_{a}\right)-I_{e}^{p l}\left(\varphi_{a}\right)=0 .
$$

Results of numerical solution of the equation (6) for cooper MP is shown in the Fig. 1,2. From the Fig. 1 it can be seen, that when the electron temperature is increasing, absolute value of MP potential is increasing as well. It can also be seen, that curve 4 has a local minimum which is caused by the increasing of electron yield from the MP surface. Fig. 2 shows, that when ion beam energy increases, absolute value of MP potential decreases. Thus, increasing of the ion beam energy leads to increasing of electron flow onto MP surface. 


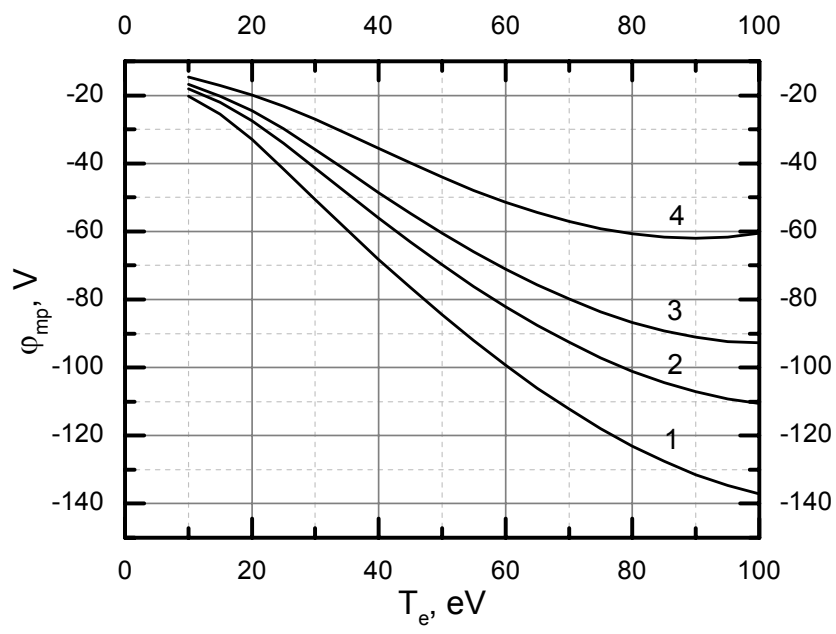

Fig. 1. The dependencies of the MP potential on the electron temperature at different energies of the ion beam $\left(1-\varepsilon_{b}=1 \mathrm{keV}, 2-\varepsilon_{b}=2 \mathrm{keV}, 3-\varepsilon_{b}=3 \mathrm{keV}, 4-\varepsilon_{b}=6 \mathrm{keV}\right)$

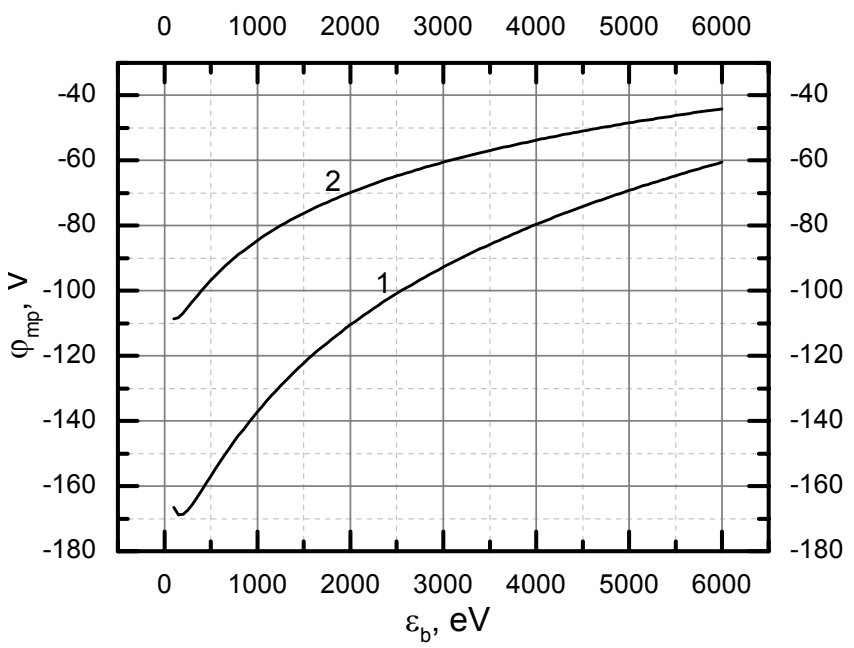

Fig. 2. The dependence of the MP potential on the ion beam energy at different electron temperatures $\left(1-\mathrm{T}_{\mathrm{e}}=100 \mathrm{eV}, 2-\mathrm{T}_{\mathrm{e}}=50 \mathrm{eV}\right)$

HEATING AND EVAPORATION OF THE MP

Absorption of the plasma ions and electrons as well as beam ions leads not only to charge transferring but also energy transferring from the plasma and ion beam that causes intensive heating of the MP. Consider the processes that are involved in energy exchange. In plasma with a Maxwellian velocity distribution of particles in the OML theory, energy flows are described by:

$$
\begin{gathered}
P_{i}=\Gamma_{i} \cdot\left(2 T_{i}+e \varphi_{a}+I\right), \\
P_{b}=\Gamma_{b} \cdot\left(\varepsilon_{b}+e \varphi_{a}+I\right), \\
P_{e}=\Gamma_{e} \cdot 2 T_{e},
\end{gathered}
$$

where $I$ is the ionization energy of an atom. The power radiated from the MP surface is described by the StefanBoltzmann law:

$$
P_{r}=4 \pi a^{2} \sigma T_{a}^{4},
$$

where $\sigma$ is the Stefan-Boltzmann constant. Energy flow due to evaporation of MP substance is described by:

$$
P_{\text {evpr }}=\Gamma_{a} \cdot\left(2 k_{B} T_{a}+p\right),
$$


where

$$
\Gamma_{a}=4 \pi a^{2} n^{\prime} \sqrt{\frac{k_{B} T_{a}}{2 \pi m_{a}}} \exp \left(-\frac{p}{k_{B} T_{a}}\right)
$$

is the flow of the evaporated atoms from the MP surface, $n^{\prime}$ is the concentration of the atoms in the metal, $p$ is the heat of evaporation of an atom.

Stationary temperature of the MP $T_{a}^{s t}$ can be found as a result of solution of the balance energy (7)-(11) equation on the MP surface:

$$
P_{i}\left(\varphi_{a}, T_{i}\right)+P_{e}\left(\varphi_{a}, T_{e}\right)+P_{b}\left(\varphi_{a}, \varepsilon_{b}\right)-P_{r}\left(T_{a}^{s t}\right)-P_{\text {evpr }}\left(T_{a}^{s t}\right)=0 .
$$

Equation (12) have been solved numerically. There were obtained dependences of stationary temperature of the MP as a function of electron temperature (Fig. 3) and ion beam energy (Fig. 4).

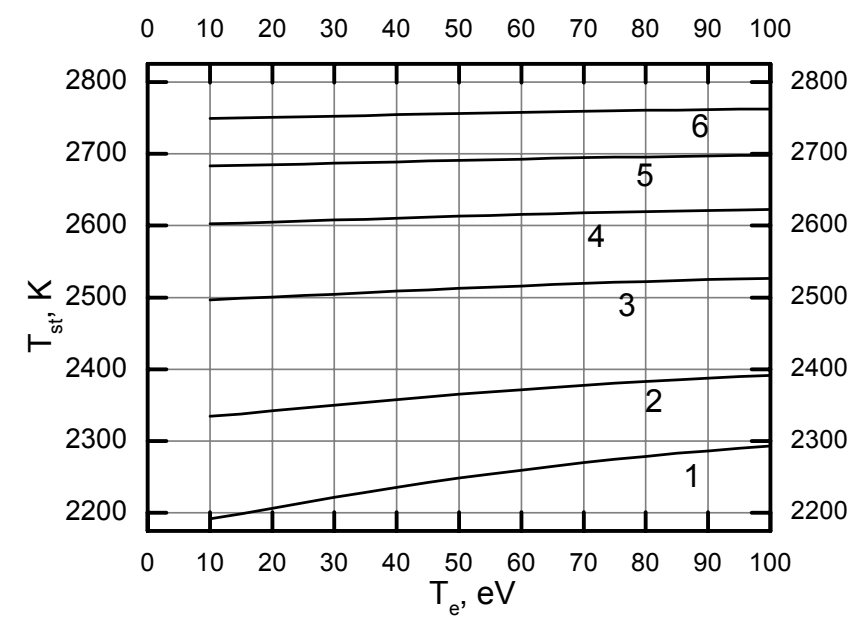

Fig. 3. Stationary temperature of the MP as a function of the electron temperature $\left(1-\varepsilon_{b}=1 \mathrm{keV}, 2-\varepsilon_{b}=2 \mathrm{keV}, 3-\varepsilon_{b}=3 \mathrm{keV}, 4-\varepsilon_{b}=4 \mathrm{keV}, 5-\varepsilon_{b}=5 \mathrm{keV}, 6-\varepsilon_{b}=6 \mathrm{keV}\right.$ )

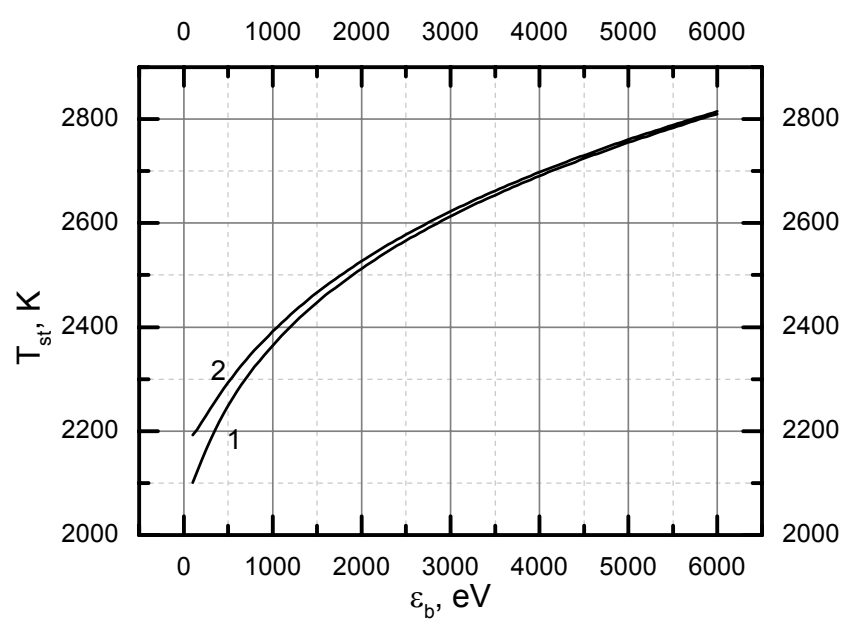

Fig. 4. Stationary temperature of the MP as a function of the ion beam energy $\left(1-T_{e}=50 \mathrm{eV}, 2-T_{e}=100 \mathrm{eV}\right)$

Numerical calculations of (12) were performed for copper, however similar results can be obtained for other metals. Fig. 3,4 show that stationary temperature strongly depends on the ion beam energy and slightly depends on the electron temperature at current parameters. The performed calculations show, that at all energies of the ion beam and electron temperatures, stationary temperature does not reach the boiling point (for cooper). Such strong cooling is achieved due to the intensive evaporation of the MP substance. 
During the evaporation (vaporization), changing of the mass of the MP substance is described by the equation:

$$
d m=\frac{P_{e v p r}\left(\varphi_{a}, T_{a}^{s t}\right) \cdot d t}{H},
$$

where $P_{e v p r}\left(\varphi_{a}, T_{a}^{s t},\right)=P_{i}\left(\varphi_{a}, T_{i}\right)+P_{e}\left(\varphi_{a}, T_{e}\right)+P_{b}\left(\varphi_{a}, \varepsilon_{b}\right)-P_{r}\left(T_{a}^{s t}\right)$ is the power which is spent to evaporation of the MP substance, $H$ is the heat of evaporation. Time of evaporation of the MP with a radius $a$ is calculated by integrating of the equality (13):

$$
t_{\text {evpr }}=\frac{4 \pi a^{3} \rho H}{3 P_{\text {evpr }}\left(\varphi_{a}, T_{a}^{s t}\right)}
$$

Results of the numerical calculations of (14) are shown in the Fig. 5,6.

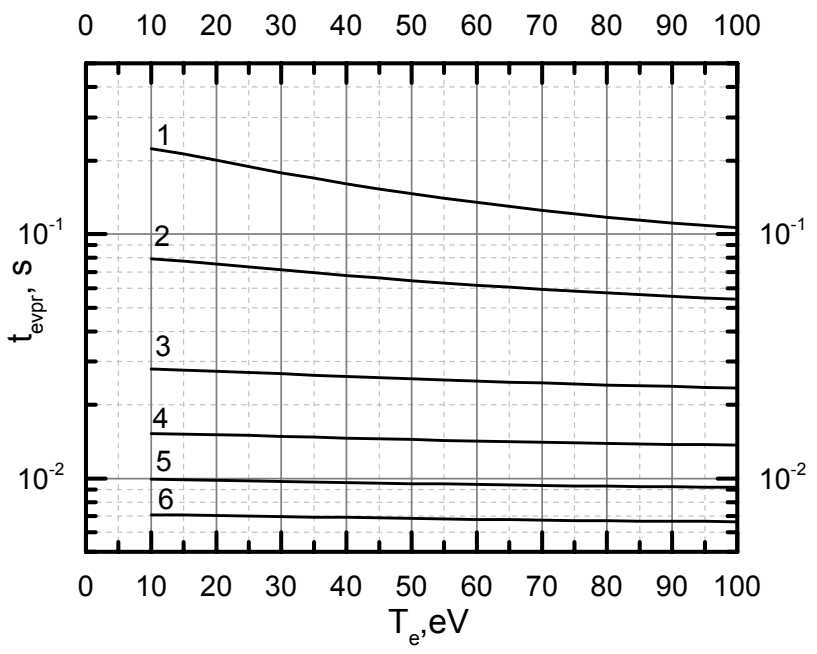

Fig.5. Dependence of the evaporation time of the MP ( $a=10 \mu \mathrm{m})$ on the electron temperature

$\left(1-\varepsilon_{b}=1 \mathrm{keV}, 2-\varepsilon_{b}=2 \mathrm{keV}, 3-\varepsilon_{b}=3 \mathrm{keV}, 4-\varepsilon_{b}=4 \mathrm{keV}, 5-\varepsilon_{b}=5 \mathrm{keV}, 6-\varepsilon_{b}=6 \mathrm{keV}\right.$ )

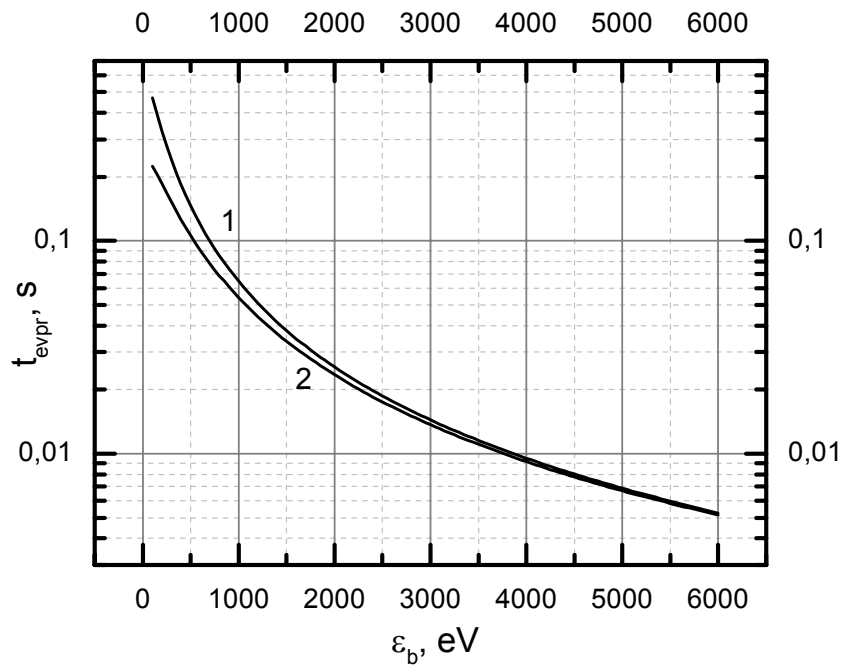

Fig. 6. Dependence of the evaporation time of the MP $(a=10 \mu \mathrm{m})$ on the ion beam energy

$$
\left(1-T_{e}=100 \mathrm{eV}, 2-T_{e}=50 \mathrm{eV}\right)
$$

The obtained results show that total evaporation time of $10 \mathrm{mkm}$ cooper MP is in the range $4 \cdot 10^{-1}-5 \cdot 10^{-3} \mathrm{~s}$ and depending on the electron temperature and ion beam energy. Evaporation of the MP takes place at temperatures below boiling point at all values of ion beam energy as well as electron temperature. Increasing of the ion beam energy significantly decrease the MP evaporation time, whereas increasing of the electron temperature gives the slight effect 
on the evaporation time at considered parameters. The ion beam provides heating of the MP by two ways: by direct transferring of ion kinetic energy due to impact with the MP surface and the following recombination; indirect way due to decrease of MP electric potential and consequently increasing energy transfer caused by the electron flow.

\section{CONCLUSIONS}

The possibility of evaporation of micro sized metallic particles in the magnetized high temperature technological plasma at presence of an ion beam in terms of OML theory has been studied. The dependencies of electric potential of the MP on the electron temperature as well as energy of the ion beam have been obtained. It has been shown that increasing of the ion beam energy leads to increases of electron flow onto MP surface since absolute value of MP potential is decreasing. The interaction of the MP with the particles of the plasma and ion beam causes intensive heating and following evaporation of the MP. Evaporation of the MP takes place at temperatures below boiling point at all considered values of ion beam energy as well as electron temperature due to intensive cooling by the evaporated atoms flow. It has been shown that total evaporation time of $10 \mathrm{mkm}$ cooper MP is in the range $4 \cdot 10^{-1}-5 \cdot 10^{-3} \mathrm{~s}$ and depends on the electron temperature and ion beam energy. Increasing of the ion beam energy significantly decrease the MP evaporation time, whereas increasing of the electron temperature without ion beam gives the slight effect on the evaporation time at considered parameters.

\section{REFERENCES}

1. Eds.R.L. Boxman, D.M. Sanders, Martin P.J. Handbook of Vacuum Arc Science and Technology: Fundamentals and Applications. NJ: Noyes Publ. 1995, P. 742.

2. Anders A. Cathodic Arcs: From Fractal Spots to Energetic Condensation. Springer Science Business Media, LLC, 2008 , p.540.

3. Aksenov I.I., Andreyev A.A., et. al. Vacuum arc: sources of plasma, deposition of coatings, surface modification. - Kiev: Naukova dumka, 2012. - P. 238-273. (in Russian)

4. Anders A., Anders S., Brown I. G. Transport of vacuum arc plasmas through magnetic macroparticle filters // Plasma Sources Sci. Technol. - 1995. - Vol. 4. - No. 1. - P. 1-12.

5. Karpov D.A. Cathodic arc sources and macroparticle filtering // Surf. Coat. Techol. - 1997. - Vol. 96. - No. 1. - P. 22-33.

6. Khoroshikh V.M. Stationary vacuum arc in technological systems for surface treatment // Physical surface engineering -2003. - Vol. 1. - No. 1. - P. 19-26. (in Russian)

7. Aksenov I.I., Belous V.A., Padalka V.G., Khoroshikh V.M. Transportation of plasma flows in a curvilinear plasma-optical system // Plasma physics. - 1978. - Vol. 4. - No. 6. - P. 758-763. (in Russian)

8. Fortov V.E., Khrapak A.G., et. al. Dusty plasma // UFN. - 2004. - Vol. 174. - No. 5. - P. 495-544. 